\title{
Aleksandra Jamrozik*
}

\section{GRAPHENE AND GRAPHENE OXIDE IN THE OIL AND GAS INDUSTRY**}

\section{INTRODUCTION}

The increase in the global population is generating a higher demand for energy materials. According to the forecasts of the International Energy Agency, energy demand shall increase by about $35 \%$ over next 20 years as compared to the present state. The main energy carriers nowadays are fossil fuels, i.e. oil, natural gas and coal and they do not have any substitutes which would satisfy the rapidly growing energy demand. The oil and gas E\&P industry is faced with the very difficult task of finding the means to meet these high demands and therefore it is looking to various innovative technological solutions, e.g. in nanotechnology.

Nanotechnology is about both the nanomaterials themselves and the tools to make and characterize them. Owing to their small dimension and highly developed surface, nanoparticles are very active chemically. The change of physicochemical properties with the finer comminution of the matter results from the need to limit the extension of crystalline lattices to microscopically finite size and the increased participation of surface atoms [42].

The dynamic development of nanotechnology over recent decades has mainly been connected with technological developments in material engineering, chemical engineering and physical analytical methods, especially with the invention of the Scanning Tunneling Microscope (STM) in 1981 and the Atomic Force Microscope (AFM) in 1986.

The division of nanomaterials most frequently used or described in patents by the top ten enterprises in the field of the oil and gas industry are presented in Figure 1.

The analysis of the presented data reveals that carbon nanotubes and carbon nanofibers are the most frequently applied nanomaterials referred to in patents registered by leading companies in the field of oil and gas industry. Another such popular nanomaterial is nanoclay, and in the third place nanosilica [40].

* AGH University of Science and Technology, Faculty of Drilling, Oil and Gas, Krakow, Poland

** This work was conducted within statutory research program No. 11. 11. 190. 555 at the Department of Drilling and Geoengineering Faculty of Drilling, Oil and Gas, AGH-UST in Krakow 


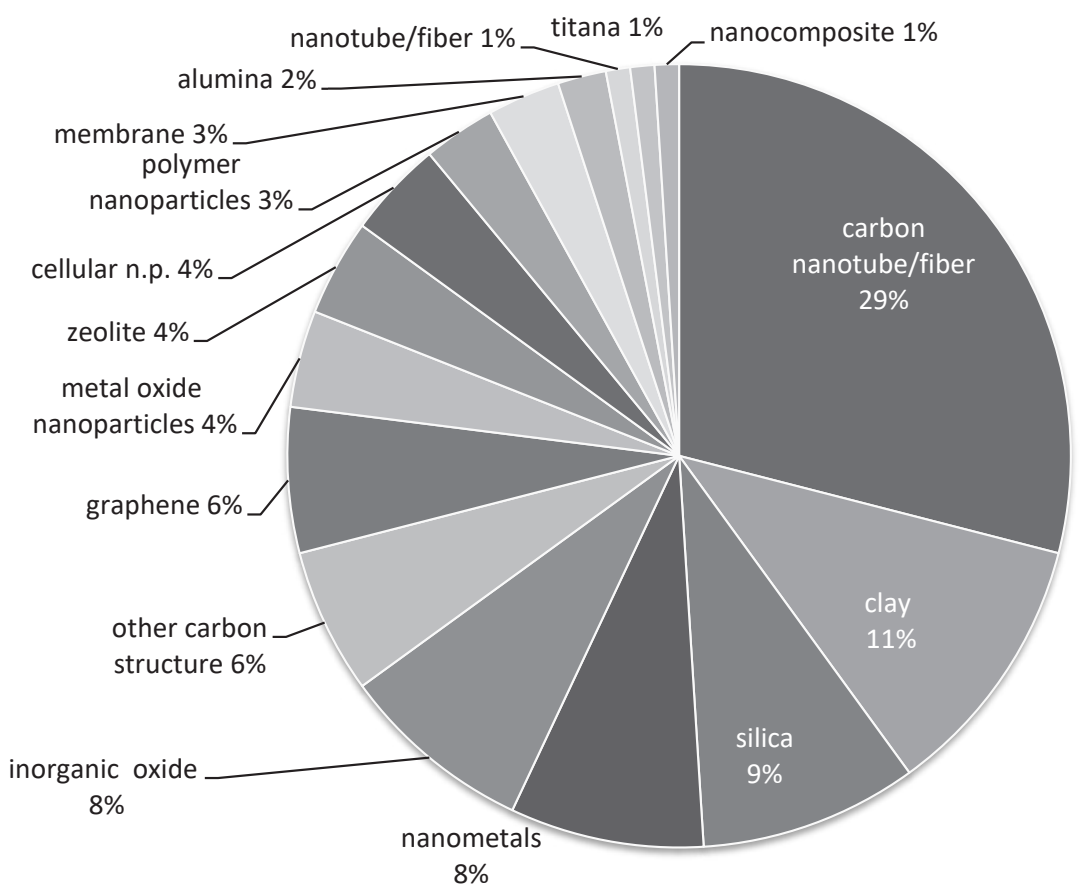

Fig. 1. Share of known nanomaterials used by top ten enterprises in the field of oil and gas industry [40]

Graphene, which is a relatively new material, occupies seventh position among the most popular nanomaterials used in oil and gas industry [40].

Graphene is a nanomaterial which has sufficiently large flakes to be identified and described for its physical properties. It was isolated only in 2004 by a team of Russian and British scientists: Konstantin Novoselov and Andre Geim, who received a Nobel Prize in Physics six years later [12]. Since that time this material has attracted rapid interest, mainly because of its unique properties.

\section{GRAPHENE AND GRAPHENE OXIDE - PROPERTIES}

Graphene was characterized as "the thinnest material in the Universe", because of the two-dimensional monolayer of carbon atoms with $\mathrm{sp}^{2}$ hybridization, organized in a flat crystalline network of characteristic hexagonal symmetry. Graphene is a basic unit of all carbon nanostructures, i.e. zero-dimensional (0D) fullerenes, (1D) rolled single-dimensional carbon nanotubes, and (3D) graphite piled up at a distance of $0.335 \mathrm{~nm}$ (3D) (Fig. 2) [24, 34].

Extensive studies on the properties of graphene proved that one of its characteristic features that it is a zero-gap semiconductor, and/or it is a semimetal. This means that the valence band and conduction band are interconnected but they do not interfere, forming the Dirac cone $[1,5,38]$. 


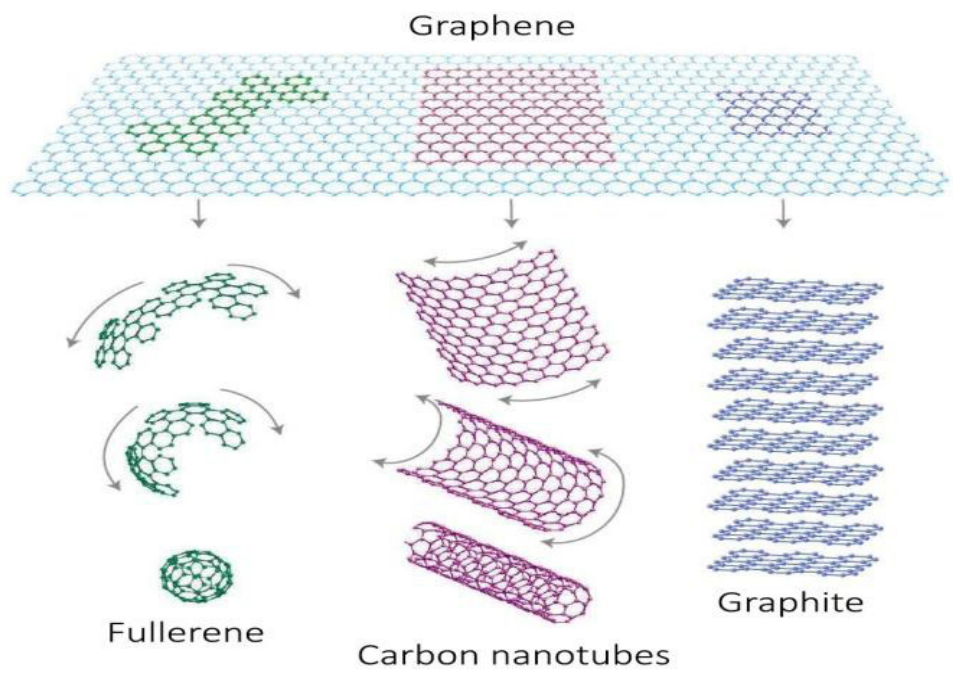

Fig. 2. Allotropic forms of carbon based on 2D graphene [12]

A unique feature of graphene is also the linear dispersive dependence of energy on momentum. The discussed properties mean that electrons in graphene are zero-mass Dirac fermions. In practice, this means high values of thermal and electric conductivity parameters, unique absorption of light and also a number of quantum phenomena [52].

Another important property of graphene as a possible application in the oil and gas industry applications are its mechanical properties. Young's modulus of graphene is $1.0 \pm 0.1 \mathrm{TPa}$, and tensile strength approaching to $130 \pm 10 \mathrm{GPa}[1,52]$.

Graphene is highly resistant to chemicals, temperature, water and organic solvents. Its large specific surface has a unique sorption capacity of chemical compounds [8].

However, the hydrophobic character of graphene means that this material changes its spatial conformation; the additional presence of van der Waals forces means that graphene undergoes agglomeration in a water environment. Thus the oxidation of graphene with strong mineral acids $\left(\mathrm{H}_{2} \mathrm{SO}_{4}, \mathrm{KMnO}_{4}, \mathrm{HNO}_{3}\right.$ ) (Hummer method) is justifiable; as a result, graphene oxide is produced and exfoliated, providing a large number of single layers of graphene oxide (GO).

The Hummer method is very efficient and allows for obtaining single-atom carbon layers of very high transparency. This method involves a large variety of oxidants, which brings about a diversification in the structure of the obtained product, and so a different quality of the end product. Accordingly, it is difficult to obtain GO of strictly defined quality and properties [38].

Graphene oxide (GO) is built of $\mathrm{sp}^{2}$ and $\mathrm{sp}^{3}$ bonded hybridized carbon atoms in a hexagonal lattice. The $\mathrm{sp}^{2}$ bonds are formed between carbon atoms or carbon atom and oxygen atom in the form of carbonyl or carboxylic groups, whereas the $\mathrm{sp}^{3}$ hybridized bonds between carbon atom and oxygen in the form of epoxy and hydroxyl groups [1,20,24]. The surface charge (zeta potential) of oxidized graphene layers dispersed in a water environment is negative, which leads to the formation of stable water dispersions [19]. 
The thermal, mechanical and electron properties of GO may change depending on the content of functional groups containing oxygen, the number of graphene layers and degree of ordering of structure.

The increase of functional groups with oxide results in a drop of thermal conductivity and monotonous lowering of the Young modulus and strength of GO because the $\mathrm{sp}^{2}$ hybridization of graphene crystalline lattice was disturbed and its energy stability decreased. Moreover, depending on the presence of $\mathrm{sp}^{3}$ bonds, oxygen atoms have a negative charge and, depending on other deficiencies, GO may be an insulator or a semiconductor $[1,52]$.

At $0.5 \%$ coverage of surface of graphene oxide with oxygen groups, the thermal conductivity lowers by $50 \%$, at $5 \%$ coverage of the GO surface with oxygen groups it lowers by $90 \%$. The minimum value of thermal conductivity (for $20 \%$ coverage with oxygen) equals to $8.8 \mathrm{~W} /(\mathrm{m} \cdot \mathrm{k})[1,49]$. Selected properties and method of producing graphene and graphene oxide are listed in Table 1.

Table 1

Selected properties and method of producing graphene and graphene oxide

\begin{tabular}{|l|c|c|c|}
\hline \multicolumn{1}{|c|}{ Properties } & Graphene & Graphene oxide & Literature \\
\hline Synthesis & $\begin{array}{c}\text { chemical vapor depo- } \\
\text { sition, thermal distri- } \\
\text { bution of SiC, delam- } \\
\text { ination of graphite }\end{array}$ & $\begin{array}{c}\text { oxidation and with delamination } \\
\text { of graphite (methods worked out } \\
\text { by Brodie, Humemers, Stauden- } \\
\text { meter with modifications) }\end{array}$ & {$[38]$} \\
\hline Carbon to oxygen ratio & no & $2-4$ & {$[35]$} \\
\hline Young modulus & $1 \mathrm{TPa}$ & $\begin{array}{c}207.6 \pm 23.4 \mathrm{GPa} \\
\text { (for GO monolayer 0.7 nm thick) }\end{array}$ & {$[46]$} \\
\hline Specific surface $\left[\mathrm{m}^{2} / \mathrm{g}\right]$ & 2630 & - & {$[1]$} \\
\hline $\begin{array}{l}\text { Electric conductivity } \\
{[\mathrm{cm} / \mathrm{Vs}]}\end{array}$ & $10000-50000$ & insulator & {$[52]$} \\
\hline $\begin{array}{l}\text { Thermal conductivity } \\
\left.\text { at temp. } 21^{\circ} \mathrm{C}[\mathrm{W} / \mathrm{m} \cdot \mathrm{k})\right]\end{array}$ & $4840-5300$ & depends on oxidation degree \\
min. 8.8 & {$[26,49]$} \\
\hline Water solubility & unsoluble & soluble & {$[35]$} \\
\hline Cost of production & high & low & {$[35]$} \\
\hline
\end{tabular}

Thanks to the properties of GO (Tab. 1), its hydrophilic character, the presence of hydroxyl and epoxy groups on the GO surface, and carboxylic or carbonyl groups on the edges of GO layers, the material easily undergoes chemical fractioning and creates considerable possibilities for organic-mineral hybridization.

The functionalization can be performed by the covalent or non-covalent method, the schematic of which is presented in Figure 3.

Graphene and its derivatives undergo non-covalence functionalization through mixing, most frequently sonification, with the use of appropriate solvents, surfactants, polymers, ionic fluids and also eutectic solvents [22]. 


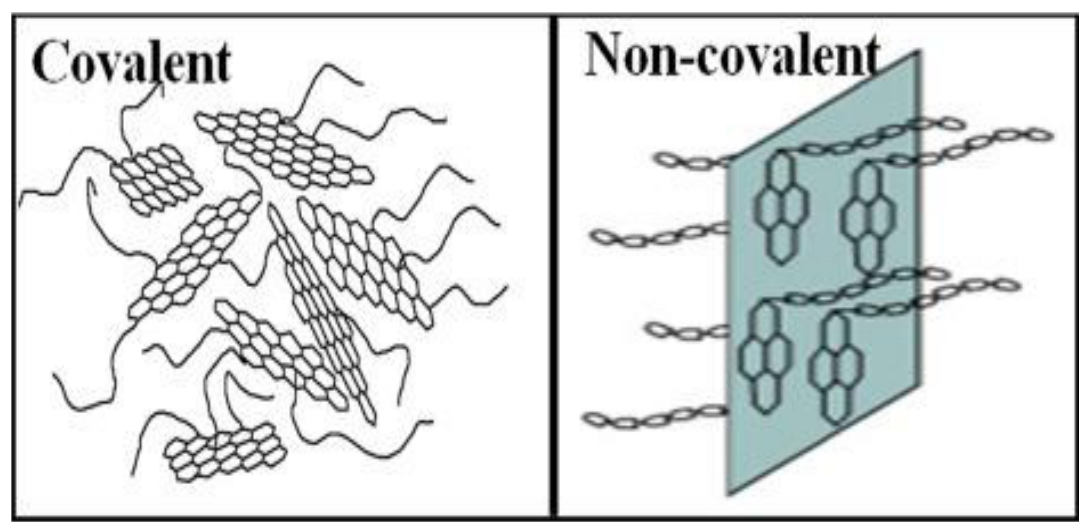

Fig. 3. Schematic of the covalent and non-covalent method [25]

Non-covalence functionalization allows for the introduction of functional groups to the surface of GO or graphene without disturbing its geometrical structure. The non-covalence modification makes use of weak $\pi$ - $\pi$, electrostatic or van der Waals molecules of organic compounds. In the course of the functionalization of graphene with the non-covalent method, the $\mathrm{sp}^{2}$ hybridization of carbon atoms remains unchanged, and $\pi$ bonds are maintained in the graphene lattice, thanks to which the material has conductive properties. The $\mathrm{sp}^{2}$ lattice of hybridized carbon atoms favors $\pi-\pi$ reactions with oligomers of the conjugated double bonds with such aromatic compounds as: sulphonic polyaniline, porphyrins and cellulose derivatives as well as nanoparticles of inorganic compounds [1, 22, 24, 25].

The covalent functionalization is based on chemical reactions, thanks to which new functional groups with oxygen are formed, including carboxylic groups on the edge of layers, and epoxy and hydroxyl groups on the surface, which participate in the modification of surface properties of GO and graphene. The covalence functionalization most frequently takes place in carboxylic groups, considerably improving their chemical affinity to solvents and polymers, deteriorating the mechanical and electrical properties because of the damaged hexagonal structure of graphene [24].

\section{THE TOXIC CHARACTER OF GRAPHENE MATERIALS}

The rapid development of nanotechnology and intensification of work on the use of graphene creates possibilities for nanoparticles to move into the environment and have an impact on living organisms. For this reason it seems absolutely necessary to perform analyses on the toxicity and cytotoxicity of this material on living organisms and the natural environment.

In one of the first such analyses it was observed that graphene had a toxic impact on Gram-negative bacteria, e.g. Escherichia coli and Gram-positive bacteria, e.g. Staphyloccoccus aureus, by destroying their cell walls [28]. The successive analyses revealed that the anti-microbiological activity of graphene depends on the graphene material, the size of flakes, way in which they are processed and also the analyses themselves [28]. 
Graphene flakes of 10-11 nm, obtained in the course of overly long sonification have an irregular surface and very sharp edges. As a consequence, graphene exhibits a $100 \times$ greater ability to induce the apoptosis pathways in RAW 264 cells [8].

The analyses also revealed that small and sharp graphene flakes killed bacteria by cutting their cell walls, leading to the disturbance of mitochondrial potential, the production of free radicals of oxygen in the cell, removal of phospholipids from the cell and the death of the bacteria [30].

During the experiments [23], author showed the anti-microbiological activity of graphene in relation to the bacteria Salmonella Enteritidis and Listeria monocytogenes. The most interesting was not the principle itself, but the way in which graphene acted on the bacteria. TEM observations revealed that graphene flakes were extremely attractive to bacteria, and acted like a magnet. However, placing themselves on the graphene flakes, especially on the sharp edges, they were killed in the course of the mechanical damage to their cell walls [23]

The experiments conducted by Liao et al. [27], who examined the cytotoxicity of GO and graphene on the human epidermis, showed a higher toxicity of graphene as compared to GO. This should be explained by the fact that GO has numerous functional groups with oxygen, thanks to which it is more hydrophilic, which consequently leads to its higher biocompatibility - the increase of oxygen groups exceeds the biocompatibility of nanomaterials [1].

The influence of graphene oxide on the human epidermis (in vitro) and the mouse epidermis (in vivo) was also analyzed by the Wang team [45]. The in vitro experiments showed to the lack of toxicity of a water dispersion of graphene oxide to $20 \mu \mathrm{g} / \mathrm{ml}$, whereas the cytotoxicity was observed to significantly increase after applying concentrations above $50 \mu \mathrm{g} / \mathrm{ml}$. GO in concentration $400 \mu \mathrm{g} / \mathrm{ml}$ showed chronic toxicity, i.e. 4/9 analyzed mice died or developed granulomatosis. GO accumulated mainly in the lungs, liver, spleen and kidneys and could not be removed from the kidneys.

Therefore, special care should be taken when handling graphene and its derivatives, gloves, special overcoats and masks should be used.

\section{USE OF GRAPHENE AND GRAPHENE OXIDE IN THE OIL AND GAS INDUSTRY}

The physicochemical properties of graphene and GO meant that these materials can be applicable in the oil and gas industry. At present the following applications in oil and gas industry can be found [2-7, 9-11, 13-18, 21, 31-33, 36, 37, 39, 41, 43, 44, 47, 48, 50, 51, 53]:

1. Exploration:

- nano-ribbons (possessing optical, magnetic and electrical properties) for hydrocarbon detection.

2. Drilling and completion:

- anticorrosion nanocoatings for rigs and platform;

- anti-wear nanocoatings for drilling equipment;

- thermal nanocoatings for drill equipment;

- nano-ribbons for reservoir temperature measurements; 
- nano-based drilling fluids to:

- reduce filtration loss,

- improve wellbore stability,

- provide efficient cooling of a drill bit,

- improve lubrication ability;

- graphene filters for selective gas-water-oil separation;

- nanocement slurry for oil well cementing jobs:

- improved cement integrity - light density,

- high strength, hole quality well placement and hermetic seals,

- improve rheology and fluid loss control;

- downhole tools - high strength nanostructure materials.

3. Production works:

- hydrophobic surface with nanostructure to scale inhibition,

- nanomembranes for treating shale gas wastewater.

4. Enhanced oil recovery operation:

- nanofluid enhanced oil recovery;

- oil-microbe detection tool using nano-optical fibers;

- nanosensor for hydrocarbon detection in oil-fields rocks;

- hydrophobic graphene as sorbent materials.

5. Refinery and distribution of crude oil and natural gas:

- nanomebranes to remove contaminations from water;

- nanomebranes for water desalination;

- anti-corrosion nanocoatings applications for pipelines;

- nanoparticles for high performance lubricant oils;

- autonomous graphene vessel for suctioning and storing liquid body of spilled oil.

The number of potential applications of graphene materials in the oil and gas industry increases each year. The analyses show the great potential of graphene materials as components of drilling fluids $[3,21,42,44,51]$.

The analysis of data presented by scientists from Rice University and Mi-Swaco [21] reveals that adding GO dispersed in alcohol to drilling muds improves the filtration properties by sealing wellbore walls. A similar phenomenon was observed after adding GO to water drilling muds [21]. A image analysis microstructure by scanning electron microscopy (SEM) of filtration cake of clay-less drilling mud with and without $15 \mathrm{wt} . \%$ of GO is presented in Figure 4.

SEM photograms of a filtration cake of clay-less drilling mud without GO which are presented in Figure 4a, prove the presence of agglomerates of high porosity, that they are built of calcite crystallites, incrusted with potassium chloride crystals. In the case of filtration cake in the clay-less mud with 1.5 wt.\% GO (Fig. 4b), there were observed crystallites of carbonate minerals incrusted with potassium chloride, with a coating of GO-modified, highly polymerized polymers. This phenomenon can be explained by the fact that GO in the presence of functional groups with oxygen easily undergoes functionalization with polymers (components of clay-less mud) on the basic surface and edges. The thus formed coating efficiently seals rock pores, preventing the penetration of water inside the rock formation. On the other hand, the GO layer which closely adheres to the wellbore walls and can be easily removed from the well under the influence of pressure differences during oil and gas exploration [51]. 
a)

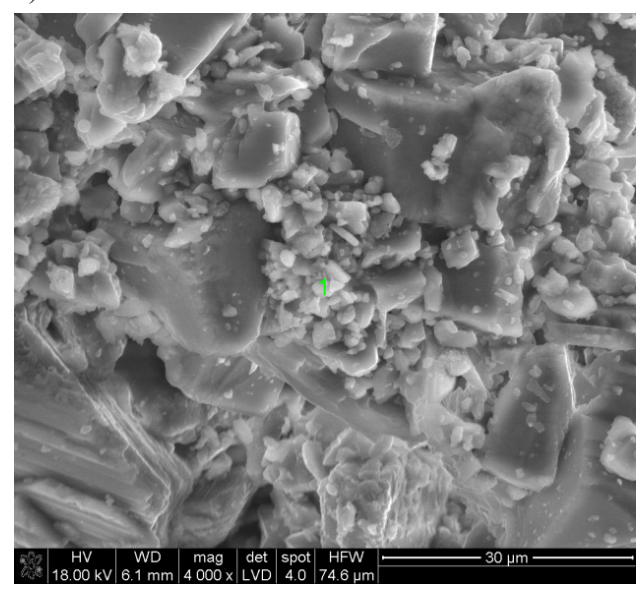

b)

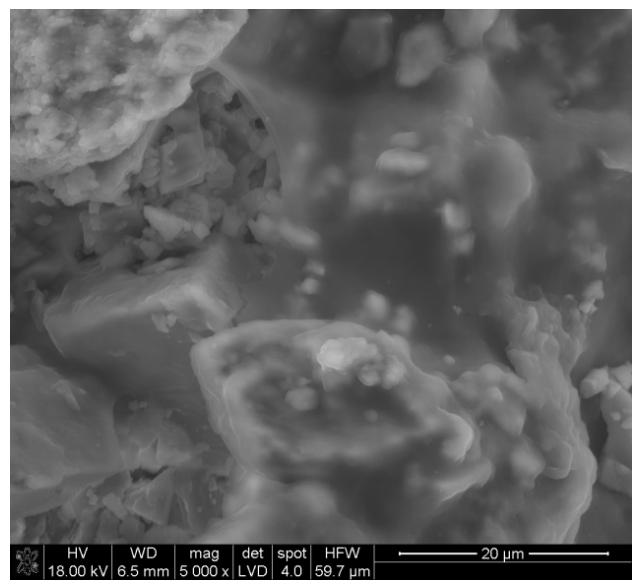

Fig. 4. SEM image showing the microstructure of a fragment of a filtration cake of clay-less drilling mud: a) sample of clay-less mud without GO added, magnif. 4000×; b) sample of clay-less mud with 1.5 wt. $\%$ GO. magnif. $5000 \times$

The tests conducted with the use of Envirocheck Contact TVC and YM (R) (Merck) on the influence of GO on the microbiological activity in biopolymeric muds (XCD) revealed that 1.5 wt. $\%$ admixture of GO limits the growth of bacteria colonies from a level of $10^{7} \mathrm{col} . / \mathrm{cm}^{3}$ to $10^{3} \mathrm{col} . / \mathrm{cm}^{3}$. Moreover, GO also reduces the development of yeast and mould. The analysis of the photos of clay-less mud with and without GO admixture (Fig. 5) reveals that a 1.5 wt.\% addition of GO practically stops the growth of mould and yeast in a mud with $\mathrm{XCD}$ biopolymer added.

a)

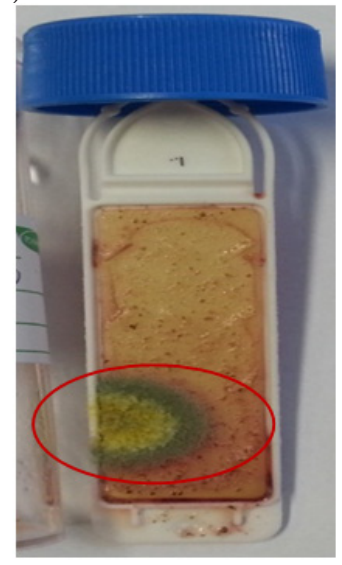

b)

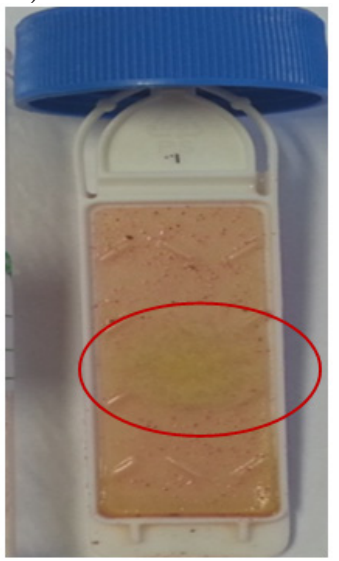

c)

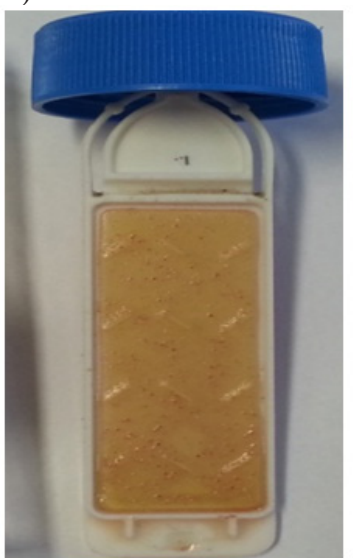

Fig. 5. Image of Envirocheck Contact YM slides dipped in clay-free mud: a) without GO - high contamination; b) with 1 wt. $\%$ of GO - low contamination; c) with $1.5 \mathrm{wt} \%$ of GO - no fungi and yeast found in mud 
The Scomi company has documented the positive influence of graphene on the lubrication properties and thermal stability of traditional drilling fluids [43]. Owing to its properties, graphene underwent agglomeration both in water and oil dispersions - continuous phases of drilling muds. Scomi subjected graphene to functionalization with surfactants and worked out two types of biodegradable additives based on graphene. The first of them was called Confi Graph Lube and was used for OBM, the second one, labeled HyPR Graph Lube, was designed for WBM. The field tests conducted in one Myanmar onshore block drilling campaigns showed that under pressure graphene particles penetrate the microscopic pores of metal forming a tribiofilm on the drill string. The following observations were made during drilling works [43]:

- coefficient of friction $(\mathrm{CoF})$ reduction from 0.21 to 0.08 ,

- longer life of the drill bit,

- torque reduction by $44 \%$ with $\mathrm{CoF}$ reduction, field recorded average reaming torque reduced by $20 \%$,

- rate of penetration (ROP) improved from an average of 3-4 m/hr to $9 \mathrm{~m} / \mathrm{hr}$ (max recorded $15 \mathrm{~m} / \mathrm{hr}$ ).

For WBM with an addition of HyPR Graph Lube the following was noted:

- plastic viscosity reduction by $23 \%$,

- fluid loss reduction by $30 \%$,

- $40 \%$ reduction in fluids loss control polymers concentration.

It should be also emphasized that tribioflim with graphene on the surface of the drill string form an efficient counter-corrosion coating. This is of special importance when drilling works are to be conducted in a corrosive environment of groundwaters or hydrogen sulfide.

Another possible application of graphene materials in the oil and gas industry is cement slurries. Investigations conducted by Sedaghat et al. showed that the incorporation of graphene in cement slurry had significant changes in the microstructural morphological, electrical and thermal properties of the slurry [36]. These properties may turn out to be especially advantageous when working out recipes of cement slurries used for sealing borehole heat exchangers. However, the most difficult aspect of incorporating clean graphene in a cement slurry is its poor dispersion in water. Therefore, first clean graphene should be dispersed in water with the use of surfactants or ultrasounds and only then introduced to the cement matrix.

GO is more easily dispersed in cement slurry, which may determine its applicability. On the other hand, oxidization of graphene results in the lowering of thermal conductivity, which from the point of view of borehole heat exchangers can be disadvantageous.

The addition of GO can lower the filtration and improve the mechanical properties of the cement matrix. The significant reinforcement of the cement matrix by GO could be attributed to the strong interfacial adhesion between GO and the cement matrix. GO sheets contain carboxylic acid groups which can react with $\mathrm{C}-\mathrm{S}-\mathrm{H}$ or $\mathrm{Ca}(\mathrm{OH})_{2}$.

The interaction may form a strong covalent bond on the interface between the GO and the matrix, and therefore increase the load-transfer efficiency from the cement matrix to GO sheets. As a result, the mechanical properties of the composite are improved [33].

One of the problems as far as the increasing costs in the oil and gas sector are concerned, is water management. The cost and complexity of processes of water filtration and 
removal create considerable problems for the operator and increase the cost of drilling. The breakthrough in the graphene production opens new possibilities to nanofiltration. At present the produced filters and membranes containing graphene can be used for volatile organic compounds removal from oil vapors, and mercury from soil and water; they can be also used as nanofilters for treating hydraulic fracturing fluids. Membranes made of graphene-based materials are water permeable and impermeable for gases [50]. For this reason, a membrane composed of many GO sheets was prepared. In this way, a multilayer membrane was produced, impermeable to gases and vapors, except water. The diaphragm was hundreds of times thinner than human hair, and yet strong, elastic and easy to handle [41].

Tests on the use of GO for treating water were also performed. For this purpose a $5 \mu \mathrm{m}$ thick GO membrane was prepared which was set in a copper basement. Thus generated molecular sieves were tested for selective adsorbing of particles of chemical compounds (e.g. $\mathrm{NaCl}, \mathrm{CuCl}_{2}, \mathrm{MgCl}_{2}$ ). The membrane was sunk in water where it slightly swelled, but where no quick water flow was possible. The filters stopped the salt ions and particles of organic compounds of a diameter bigger than $9 \AA$; the smaller ones went with the water [15].

$\mathrm{GO}$ can be also used as a medium for radionuclide removal from salt solutions. GO has a large specific surface and is very sorptive, therefore the radionuclides are mechanically caught by graphene. After adding GO to contaminated water, they form solid particles in the solution, which can be easily removed (Fig. 6). This solution was first proposed by scientists from the Moscow State University and James Tour from the University of Houston for treating contaminated water after the catastrophe in the Fukushima nuclear power station [29].

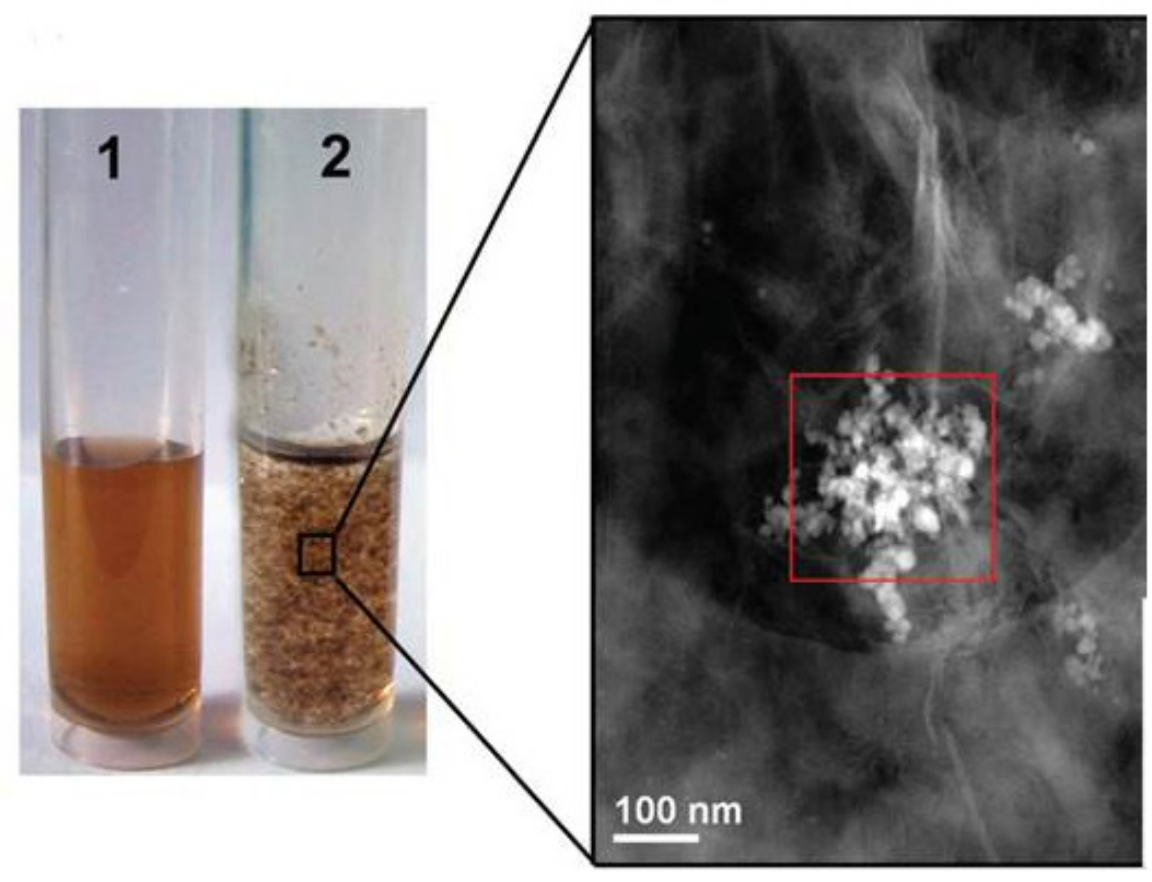

Fig. 6. Contaminated water after adding graphene oxide [29] 
GO acts quickly and efficiently. The GO flakes were able to clean radioactive water in a few minutes. At a concentration lower than $0.1 \mathrm{~g}$ of GO per 1 liter of fluid, the sorption of radionuclids finished after 5 minutes, removing about $95 \%$ of plutonium $(\mathrm{Pu})$, americium (Am) and thorium (Th) and about $55 \%$ of uranium (U). In the treated solution sodium, calcium, and other substances (sulfates, acetates, citrate) were also found which did not disturb the sorption of actinides $[29,36]$.

Apart from the discussed publications, the graphene materials can also be used in borehole geophysics for providing data about the geological properties of reservoir rocks. At present research works are being realized on the use of magnetic graphene nano-ribbons (MGNRs) in drilling muds. The use of nano-ribbons as, e.g. components of drilling fluids may help work out new measurement techniques and provide more data about the reservoir rocks [14].

\section{SUMMARY}

The analyses of graphene and GO as a material for the oil and gas industry reveals that the perspectives are promising. The addition of graphene and GO to oil- and water-based muds can be especially advantageous when drilling horizontal boreholes or in extreme conditions, i.e. at considerable depth or in unconventional reservoirs.

The results of tests on the use of graphene and GO to the remediation of ground and water environment, as well as for treating drilling fluids or wastewater with nanomaterials, are very interesting.

GO is also a good component of sealing slurries because it contributes to the improvement of mechanical properties of hardened cement stone. It should be also emphasized that graphene materials have great potential and can be used to help develop geothermal resources by improving their thermal conductivity. Besides they can be used for the production of corrosion resistant materials to be used for geothermal production.

The use of graphene in drilling technology can be possible only when economic profits are in view. The economic situation may be the cause of moderate rate at which graphene and GO are implemented in drilling industry. The price of graphene products has recently decreased, e.g. now 51 of GO water solution costs only $\$ 571$, as compared to its previous price of ca. $\$ 300$ for 0.51 .

\section{REFERENCES}

[1] Aleksandrzak M.: Badania nad synteza i funkcjonalizacja grafenu i tlenku grafenu. Szczecin 2015 [doctoral thesis].

[2] Babak F., Abolfazl H., Alimorad R., Parviz G.: Preparation and Mechanical properties of Graphene Oxide: Cement Nanocomposites. The Scientific World Journal, 16 January 2014, doi.org/10.1155/2014/276323.

[3] Backer Hughes Incorporated: Graphene-containing Fluids for Oil and Gas exploration and production, 2012.

[4] Berman D., Erdemir A., Sumant A.: Few layer graphene to reduce wear and friction on sliding steel surfaces. Carbon, vol. 54, 2013, pp. 454-459. 
[5] Bong J., Lim T, Seo K., Kwon Ch., Park J., Kwak S., Ju S., Dynamic graphene filters for selective gas-water-oil separation. Scientific Reports, vol. 5, 2015.

[6] Casey T.: Methane To The Rescue! New Energy Efficient Graphene Desalination Membrane For The 99\%. Clean Technica, 3.04.2015.

[7] Cocuzza M., Pirri C., Rocca V., Verga F.: Current and Future Nanotech Applications in the Oil Industry. American Journal of Applied Sciences, vol. 9, no. 6, 2012, pp. 784-793.

[8] Dudek I., Skoda M., Jarosz A.: Medycyna w skali nano-grafen. In: M. Olszówka, K. Maciąg (red.), Nowoczesne trendy w medycynie. Fundacja na rzecz Nauki i Rozwoju ,Tygiel”, Lublin 2015.

[9] El-Diasty A.I., Salem Ragab A.M.: Applications of Nanotechnology in the Oil \& Gas Industry: Latest Trends Worldwide \& Future Challenges in Egypt. North Africa Technical Conference and Exhibition, 15-17 April 2013, Cairo, Egypt, SPE-164716-MS.

[10] Fridheim J. Young s., De Guido S., Lee J., Guo Q.: Nanotechnolgy for Oilfield Application - Hype or Reality? SPE International Oilfield Nanotechnology Conference in Noordwijk, The Netherlands, 12-14 June 2012.

[11] Graphene in the oil and gas industry. Graphene \& 2D Materials Magazine, iss. 4, http:// www.2dmaterialsmag.com/issue-4-graphene-in-the-oil-graphene-in-asia-graphenequantum-dots [23.02.2017].

[12] Geim A.K., Novoselov K.S.: The rise of graphene. Nature Materials, vol. 6, 2007, pp. 183-191.

[13] Hoelscher K.P., Young S., Friedheim J., de Guido S.: Nanotechnology Application in drilling fluids. $11^{\text {th }}$ Offshore Mediterranean Conference and Exhibition in Ravenna, Italy, 20-22 March 2013.

[14] Jonhnson K.: Advances in Nanotechnology Holde Huge Potential Promise in Upstream Application. The American Oil \& Gas Reporter, 2014.

[15] Joshi R.K., Carbone P., Wang F.C., Kravets V.G., Su Y., Grigorieva I.V., Wu H.A., Nair G.: Precise and Ultrafast Molecular Sieving Through Graphene Oxide Membranes. Science, February 14, vol. 343, iss. 6172, 2014, pp. 752-754, doi:10.1126/ science. 1245711.

[16] Kapusta S., Balzano, Te Riele P.: Nanotechnology Applications in Oil and Gas Exploration and Production. International Petroleum Technology Conference, Bangkok, Thailand, 7-9 February 2012.

[17] Kasiralvalad E.: The graet potencial of nanomaterials in drilling and drilling fluid application. International Journal of Nano Dimension, vol. 5, 2014, pp. 463-471 (special issue).

[18] Kim T., Lee J., S., Lee G., Seo D.K., Baek Y., Yoon J., Oh S.M., Kang J., Kim Y.H.: Autonomous Graphene Vessel for Suctioning and Storing Liquid Body of Spilled Oil. Scientific Reports, vol. 6, 2016, doi:10.1038/srep22339.

[19] Konkena B., Vasudevan S.: Understanding Aqueous Dispersibility of Graphene Oxide and Reduced Graphene Oxide through $p K_{a}$ Measurements. The Journal of Physical Chemistry Letters, vol. 3, no. 7, 2012, pp. 867-872.

[20] Konios D., Stylianakis M.M., Stratakis E., Kymakis E.: Dispersion behaviour of graphene oxide and reduced graphene oxide. Journal of Colloid and Interface Science, vol. 15, September 2014, pp. 108-112. 
[21] Kosynkin D., Ceriotti G., Wilson K.C., Lomeda J.R., Scorsone J.T., Patel A.D., Friedheim J.E., Tour J.M.: Graphene Oxide as a High-Performance Fluid-Loss-Control Additive in Water-Based Drilling Fluids. ACS Appl. Mater. Interfaces, vol. 4(1), 2012, pp. 222-227, doi:10.1021/am2012799.

[22] Kugler Sz., Spychaj T.: Nanostruktury węglowe i błony lub powtoki polimerowe z ich udziałem. Cz. 1. Charakterystyka ogólna, funkcjonalizacja oraz metody badań kompozycji z nanorurkami lub grafenami. Polimery 2013.

[23] Kurantowicz N. et al.: Interaction of graphene family materials with Listeria monocytogenes and Salmonella enterica. Nanoscale Res Lett. 2015, vol. 10, no. 23.

[24] Laskowska A., Lipińska M., Zaborski M.: Zastosowanie grafenu w kompozytach polimerowych. Przemysł Chemiczny, vol. 91, no. 5, 2012, pp. 841-845.

[25] Layek R., Nandi A.: A review on synthesis and properties of polymer functionalized graphene. Polymer, vol. 54, iss. 19, 23 August 2013, pp. 5087-5103.

[26] Li F., Jiang X., Zhao J., Zhang S.: Graphene oxide: A promising nanomaterial for energy and environmental applications. Nano Energy, vol. 16, September 2015, pp. 488-515, http://dx.doi.org/10.1016/j.nanoen.2015.07.014.

[27] Ken-Hsuan Liao, Yu-Shen Lin, Macosko Ch.W., Haynes Ch.L.: Cytotoxicity of graphene oxide and graphene in human erythrocytes and skin fibroblasts. ACS Appl Mater Interfaces, vol. 3, no. 7, 2011, pp. 2607-2615.

[28] Liu S., Zeng T.H., Hofmann M., Burcombe E., Wei J., Jiang R., Kong J., Chen Y.: Antibacterial activity of graphite, graphite oxide, graphene oxide, and reduced graphene oxide: membrane and oxidative stress. ACS Nano., vol. 5, 27 September 2011, pp. 6971-6980, doi:10.1021/nn202451x.

[29] Ho M.W.: Graphene Oxide for Nuclear Decontamination. Institute of Science in Society, 17 March 2013.

[30] Mertens R.: The Graphene Handbook, Third edition. Lulu Enterprises Incorporated, Raleigh 2016.

[31] Noveiri E., Torfi S.: Nano Coating Application for Corrosion Reduction in Oil and Gas Transmission Pipe: A Case Study in South of Iran. International Conference on Advanced Materials Engineering IPCSIT, vol. 15, IACSIT Press, Singapore, 2011.

[32] Nader Nabhani, Milad Emami: Significance of Nanotechnology in Oil and Gas Offshore Engineering. 4th International Conference on Mechanical, Automotive and Materials Engineering (ICMAME'2014) Jan. 28-29, 2014 Bangkok (Thailand).

[33] Pan Z., He L., Qiu L., Korayem A.H., Li G., Zhu J.W., Collins F., Li D., Duan W.H., Wang M.C.: Mechanical properties and microstructure of a graphene oxide-cement composite. Cement and Concrete Composites, vol. 58, February 2015, pp. 140-147.

[34] Papageorgiou D., Kinlach I., Young R.: Graphenelelastomer nanocomposites. Carbon 2015.

[35] Perrault F., Fonseca de Faria A., Elimelech M.: Environmental applications of graphene - based nanomaterials. Royal Society of Chemistry, 9 January 2015.

[36] Romanchuk A.Yu., Slesarev A.S., Kalmykov S.N., Kosynkin D.V., Tour J.M.: Graphene oxide for effective radionuclide removal. Physical Chemistry Chemical Physics, vol. 15, 2013, pp. 2321-2327.

[37] Sedaghat A., Ram M.K., Zayed A., Kamal R., Shanahan N.: Investigation of physical properties of Graphene-Cement Composite for Structural Application. OJCM, vol. 4, 2014, pp. 12-21. 
[38] Smędowski L., Muzyk R.: Grafen - metody otrzymywania a zastosowanie i właściwości. Karbo 2013, nr 2, pp. 128-136.

[39] Sunjay: Nano-Science \& Technology in Upstream. $8^{\text {th }}$ Biennial International Conference \& Exposition on Petroleum Geophysics, 2010.

[40] StatNano: Application of Nanotechnology in Petroleum Industry Based on Active Enterprises. January 2016.

[41] Surwade S.P., Smirnov S.N., Vlassiouk I.V., Unocic R.R., Veith G.M., Dai S., Mahurin S.M.: Water desalination using nanoporous single-layer graphene. Nature Nanotechnology, vol. 10, 2015, pp. 459-464, doi:10.1038/nnano.2015.37.

[42] Szewczyk P.: Nanotechnologie: aspekty techniczne, środowiskowe i społeczne. Monografia. Wyd. Politechniki Śląskiej, Gliwice 2011.

[43] Taha M.N., Lee S.: Nano Graphene Application Improving Drilling Fluids Performance. International Petroleum Technology Conference in Doha, Qatar, 6-9 December 2015.

[44] Tour J.M., Schmidt H.K., Lomeda J.R., Kosynkin D.V., Doyle C.D.: Graphene compositions and drilling fluids derived therefrom. Patent US 8183180 B2, 2012.

[45] Wang K., Ruan J., Song H., Zhang J., Guo S., Cui D.: Biocompatibility of Graphene Oxide. Nanoscale Research Letters, vol. 6, no. 1, 2011, doi:10.1007/s11671-010-9751-6 PMCID: PMC3212228.

[46] Suk J.W., Piner R.D., An J., Ruoff R.S.: Mechanical Properties of Monolayer Graphene Oxide. ACS Nano, vol. 4, no. 11, 2010, pp. 6557-6564.

[47] Qin D., Liu Z., Sun D., Song X., Bai H.: A new nanocomposite forward osmosis membrane custom-designed for treating shale gas wastewater. Scientific Reports, vol. 5, 2015, doi:10.1038/srep14530.

[48] Qu X., Alvarez P., Li Q.: Application of nanotechnology in water and wastewater treatment. Water Reasearch, vol. 47, 12 August 2013., pp. 3931-3946.

[49] Mu X., Wu X., Zhang T., Go D., B., Luo T.: Thermal Transport in Graphene Oxide - From Ballistic Extreme to Amorphous Limit. Scientific Reports, vol. 4, 2014, doi:10.1038/srep03909.

[50] Xu Q., Xu H., Lv Y., Dong Ch., Sreeprasad T.S.: Graphene and graphene oxide: advanced membranes for gas separation and water purification. Inorganic Chemistry Frontiers, iss. 5, 2015.

[51] Xuan Y., Jiang G.: Nanographite Oxide as Ultrastrong Fluid-Loss-Control Additive in Water-Based Drilling Fluids. Journal of Dispersion Science and Technology, vol. 35, 2014, pp. 1386-1392.

[52] Zhu Y., Murali S.: Graphene and graphene oxide: synthesis, properties, and applications. Advanced Materials, vol. 22, iss. 3, 15 September 2010, pp. 3906-3924, doi: 10.1002/adma.201001068.

[53] Zhang Y., Tang T., Girit C., Hao Z., Martin M.C., Zettl A., Crommie M.F., Shen Y.R., Wang F.: Direct observation of a widely tunable bandgap in bilayer grapheme. Nature, vol. 459, 2009, pp. 820-823, doi:10.1038/nature08105. 